This item was submitted to Loughborough's Research Repository by the author.

Items in Figshare are protected by copyright, with all rights reserved, unless otherwise indicated.

\title{
Stability constants of U(VI) and U(IV)-humic acid complexes
}

PLEASE CITE THE PUBLISHED VERSION

PUBLISHER

(C) Springer Science + Business Media

LICENCE

CC BY-NC-ND 4.0

REPOSITORY RECORD

Warwick, Peter, Nicholas D.M. Evans, Tony Hall, Gareth Walker, and E. Steigleder. 2019. "Stability Constants of U(VI) and U(iv)-humic Acid Complexes". figshare. https://hdl.handle.net/2134/3081. 
This item was submitted to Loughborough's Institutional Repository by the author and is made available under the following Creative Commons Licence conditions.

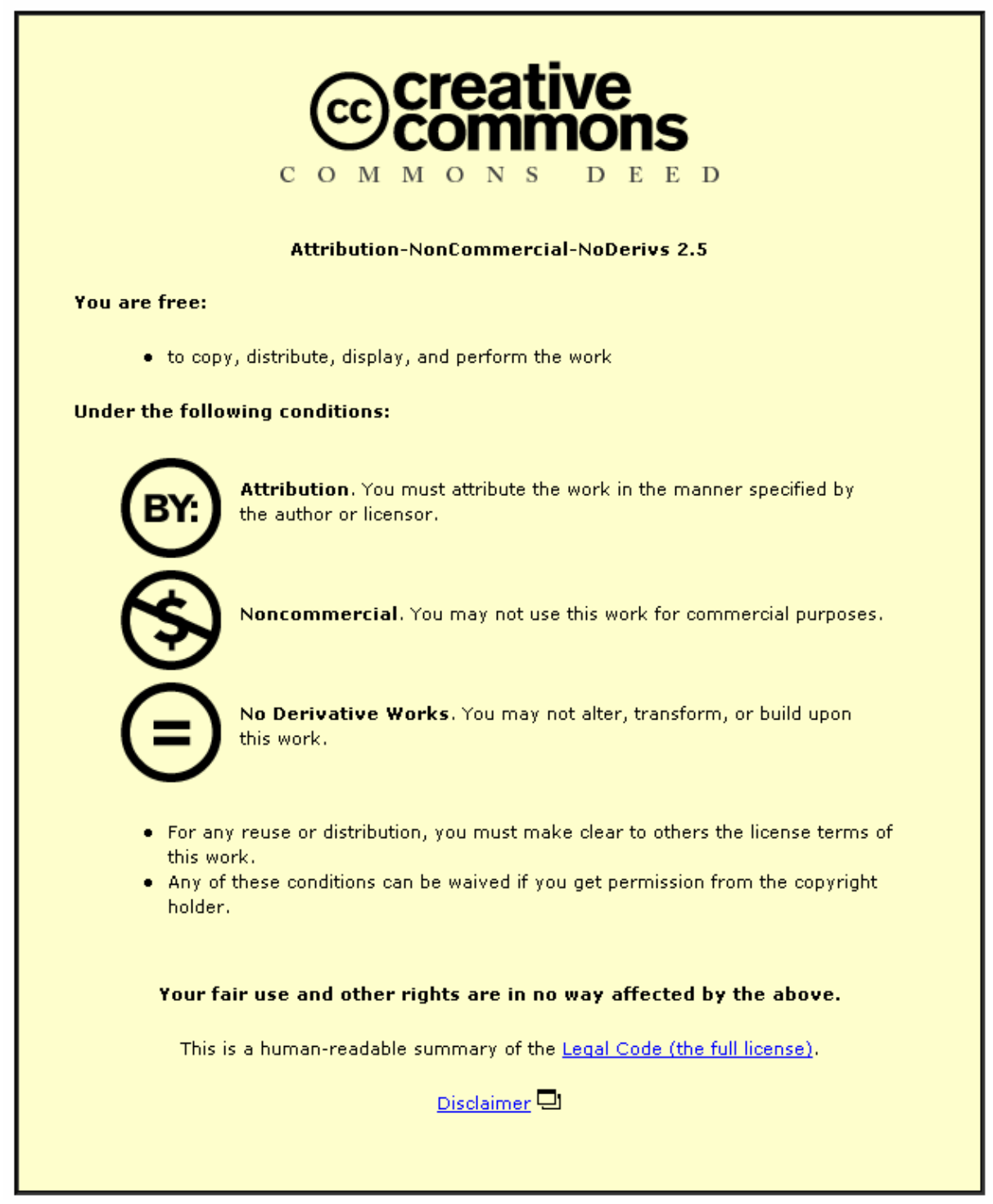

For the full text of this licence, please go to: http://creativecommons.org/licenses/by-nc-nd/2.5/ 
Stability constants of $\mathrm{U}(\mathrm{VI})$ and $\mathrm{U}(\mathrm{IV})$-humic acid complexes

P. Warwick*, N. Evans, A. Hall, G. Walker, E. Steigleder

Department of Chemistry, Loughborough University, Loughborough, Leics. LE11 3TU, UK.

*Author for correspondence (E-mail: p.warwick@lboro.ac.uk) 


\begin{abstract}
Conditional stability constants have been determined for $\mathrm{U}(\mathrm{IV})$ and $\mathrm{U}(\mathrm{VI})$ Boom Clay humic acid (BCHA) and Aldrich humic acid (AHA) complexes, under anaerobic and carbonate free conditions. The constants are needed for nuclear waste repository performance assessment purposes. The U(IV) constants were obtained by developing an approach based on the solubility product of amorphous $\mathrm{U}(\mathrm{OH})_{4}$. The $\mathrm{U}(\mathrm{VI})$ constants were obtained by applying the Schubert ion exchange approach.
\end{abstract}




\section{Introduction}

A nuclear waste repository may be constructed underground in the Belgian Boom Clay ( $\mathrm{BC}$ ) geological formation. $\mathrm{BC}$ is highly impervious but contains relatively large amounts of interstitial $\mathrm{BCHA}$. Mobile and immobile fractions are present, capable, in principle, of exerting opposing effects on metal transport due to the formation of metal humate complexes [1]. The mobile and immobile forms exhibit similar complexing tendencies, but the immobile form is more abundant. Clearly, radionuclide humic acid stability constants are needed for repository performance assessment purposes.

This particular study was undertaken to obtain U(IV) and U(VI) - BCHA constants. Various $\mathrm{U}(\mathrm{VI}) \mathrm{HA}$ values can be found in the literature, see for example the fluorescence study by Saito and co-workers [2], and the references contained therein. Unfortunately, the reported constants are generally conditional, and relate to $\mathrm{pH}$ values less than 7.0 , for example Czerwinski et al. reported for Gorleben $\mathrm{HA}, \log \beta=6.16 \pm 0.13$ at $\mathrm{pH}=4.0$ [3]. $\mathrm{BC}$ interstitial water has a $\mathrm{pH}$ of approximately 8.2. The $\mathrm{U}(\mathrm{IV})-\mathrm{HA}$ value is particularly important because many possible far-field conditions, such as Boom Clay, are reducing. The solubility of crystalline $\mathrm{UO}_{2}$ in Boom Clay conditions has been measured by Cachoir et al [4]. The solubility was found to vary between $3 \times 10^{-8}$ and $1.5 \times 10^{-6} \mathrm{~mol} \mathrm{dm}^{-3}$.

The experiments were conducted using purified AHA and BCHA extracted from the clay at the underground research facility at Mol in Belgium, at a depth of $223 \mathrm{~m}$ [1]. The extract was concentrated using the diethyl-aminoethyl cellulose procedure of Miles et al [5]. The U(IV) constants were obtained by developing an approach based on the 'solubility product' of the solid phase precipitated under alkaline conditions and assumed to be $\mathrm{U}(\mathrm{OH})_{4}(\mathrm{am})$. The $\mathrm{U}(\mathrm{VI})$ constants were obtained by employing the 'classical' Schubert ion-exchange approach [6]. The experiments were performed at $\mathrm{pH}$ values of relevance to environmental conditions, with $\mathrm{O}_{2}$ and $\mathrm{CO}_{2}$ excluded. For comparative purposes $\mathrm{U}(\mathrm{IV})$ and $\mathrm{U}(\mathrm{VI})$ - AHA constants were also determined using similar conditions. 


\subsection{Solubility product approach for U(VI) constants}

The solubility product approach involved three stages,

(i) precipitation and ageing of amorphous $\mathrm{U}(\mathrm{OH})_{4}$,

(ii) equilibration with $\mathrm{BCHA}$ or $\mathrm{AHA}$, and

(iii) supernatant activity measurements.

In the first stage uranyl nitrate $\left(\mathrm{UO}_{2}\left(\mathrm{NO}_{3}\right)_{2}\right)$ solution, containing a tracer amount of ${ }^{233} \mathrm{U}$, was treated with sodium dithionite $\left(\mathrm{Na}_{2} \mathrm{~S}_{2} \mathrm{O}_{4}\right)$ under alkaline conditions in the absence of air and carbonate. The yellow $\mathrm{U}(\mathrm{VI})$ solution was reduced to $\mathrm{U}(\mathrm{IV})$ and grey/brown amorphous $\mathrm{U}(\mathrm{OH})_{4}$ precipitated. The precipitates were aged for 2 weeks. The reactions can be represented as:

$$
\mathrm{UO}_{2}^{2+}+\mathrm{S}_{2} \mathrm{O}_{4}^{2-} \rightleftharpoons \mathrm{U}^{4+}+2 \mathrm{SO}_{3}^{2-}
$$

and

$$
\mathrm{U}^{4+}+4 \mathrm{OH}^{-} \rightleftharpoons \mathrm{U}(\mathrm{OH})_{4}
$$

Uranium (IV) hydroxide is very sparingly soluble. The dissolution can be represented as the reverse of the formation reaction, i.e.:

$$
\mathrm{U}(\mathrm{OH})_{4} \rightleftharpoons \mathrm{U}^{4+}+4 \mathrm{OH}^{-}
$$

The solubility product $\left(\mathrm{K}_{\mathrm{sp}}\right)$ is given by:

$$
\mathrm{K}_{\mathrm{sp}}=\left[\mathrm{U}^{4+}\right]\left[\mathrm{OH}^{-}\right]^{4}
$$

Under hydrolysing conditions in the absence of HA, speciation studies show that the total $\mathrm{U}(\mathrm{IV})$ concentration in solution $\left([\mathrm{U}]_{\mathrm{sol}}\right.$ ) can be expressed as:

$$
[\mathrm{U}]_{\mathrm{sol}}=\left[\mathrm{U}^{4+}\right]+\left[\mathrm{U}(\mathrm{OH})^{3+}\right]+\left[\mathrm{U}(\mathrm{OH})_{2}^{2+}\right]+\left[\mathrm{U}(\mathrm{OH})_{3}^{+}\right]+\left[\mathrm{U}(\mathrm{OH})_{4}\right]
$$

Hence: 


$$
\begin{aligned}
{[U]_{\text {sol }} } & =\left[\mathrm{U}^{4+}\right]+\beta_{1}\left[\mathrm{U}^{4+}\right]\left[\mathrm{OH}^{-}\right]+\beta_{11}\left[\mathrm{U}^{4+}\right]\left[\mathrm{OH}^{-}\right]^{2}+\beta_{111}\left[\mathrm{U}^{4+}\right]\left[\mathrm{OH}^{-}\right]^{3}+\beta_{1 \mathrm{~V}}\left[\mathrm{U}^{4+}\right]\left[\mathrm{OH}^{-}\right]^{4} \\
& =\left[\mathrm{U}^{4+}\right]\left\{1+\beta_{1}\left[\mathrm{OH}^{-}\right]+\beta_{11}\left[\mathrm{OH}^{-}\right]^{2}+\beta_{111}\left[\mathrm{OH}^{-}\right]^{3}+\beta_{1 \mathrm{~V}}\left[\mathrm{OH}^{-}\right]^{4}\right\} \\
& =\left[\mathrm{U}^{4+}\right] \mathrm{A}
\end{aligned}
$$

Where $\beta_{1}, \beta_{11}, \beta_{111}$ and $\beta_{1 V}$ are the stability constants of the various hydrolysis products, and $\mathrm{A}$ is a $\mathrm{pH}$ dependent constant, known as the side reaction coefficient [7].

After ageing, the precipitates were treated with $\mathrm{HA}$. Since $\mathrm{U}^{4+}$ may react with humic acids to form binary and ternary (i.e. mixed) complexes [8], the dissolved uranium concentration $\left([\mathrm{U}]_{\text {sol }}\right)$ in the presence of HA may be expressed as:

$[\mathrm{U}]_{\mathrm{sol}}=\left[\mathrm{U}^{4+}\right] \mathrm{A}+[\mathrm{UHA}]+[\mathrm{U}(\mathrm{OH}) \mathrm{HA}]+\left[\mathrm{U}(\mathrm{OH})_{2} \mathrm{HA}\right]+\left[\mathrm{U}(\mathrm{OH})_{3} \mathrm{HA}\right]+\left[\mathrm{U}(\mathrm{OH})_{4} \mathrm{HA}\right]$ (iv)

Hence, the total humate complex concentration is given by:

$[U]_{\text {sol }}-\left[U^{4+}\right] A=B\left[U^{4+}\right][\mathrm{HA}]+\beta_{1}\left[U^{4+}\right][\mathrm{HA}]\left[\mathrm{OH}^{-}\right]+\beta_{2}\left[\mathrm{U}^{4+}\right][\mathrm{HA}]\left[\mathrm{OH}^{-}\right]^{2}+\beta_{3}\left[\mathrm{U}^{4+}\right][\mathrm{HA}]\left[\mathrm{OH}^{-}\right]^{3}+\beta_{4}\left[\mathrm{U}^{4+}\right][\mathrm{HA}]\left[\mathrm{OH}^{-}\right]^{4}$

Rearrangement of equation ( $v$ ) allows an experimental stability constant ( $\left.\beta_{\exp }\right)$ to be defined i.e.:

$$
\begin{aligned}
\frac{[\mathrm{U}]_{\text {sol }}-\left[\mathrm{U}^{4+}\right] \mathrm{A}}{\left[\mathrm{U}^{4+}\right][\mathrm{HA}]} & =\beta+\beta_{1}\left[\mathrm{OH}^{-}\right]+\beta_{2}\left[\mathrm{OH}^{-}\right]^{2}+\beta_{3}\left[\mathrm{OH}^{-}\right]^{3}+\beta_{4}\left[\mathrm{OH}^{-}\right]^{4} \\
& =\beta_{\exp }
\end{aligned}
$$

From equation (i)

$$
\left[\mathrm{U}^{4+}\right]=\frac{\mathrm{K}_{\mathrm{sp}}}{\left[\mathrm{OH}^{-}\right]^{4}}
$$

Therefore: 


$$
\beta_{\exp }=\frac{[\mathrm{U}]_{\mathrm{sol}}-\left(\frac{\mathrm{K}_{\mathrm{sp}}}{\left[\mathrm{OH}^{-}\right]^{4}}\right) A}{\left(\frac{\mathrm{K}_{\mathrm{sp}}}{\left[\mathrm{OH}^{-}\right]^{4}}\right)\left([\mathrm{HA}]_{\mathrm{total}}-\left([\mathrm{U}]_{\mathrm{sol}}-\left(\frac{\mathrm{K}_{\mathrm{sp}}}{\left[\mathrm{OH}^{-}\right]^{4}}\right) \mathrm{A}\right)\right)}
$$

$\beta_{\text {exp }}$ values were calculated using equation (vii) from the measured supernatant activities, the $\mathrm{HA}$ concentrations and $\mathrm{pH}$ values. The $\mathrm{K}_{\mathrm{sp}}$ value was obtained by determining the solubility of the precipitate in the absence of HA.

\subsection{Schubert ion exchange approach for $\mathrm{U}(\mathrm{VI})$ constants}

The standard Schubert method was applied by placing ${ }^{233} \mathrm{U}$ tracer in contact with a cation exchange resin ( $\mathrm{Na}$ form), in the presence and absence of varying amounts of $H A$. Appropriate $D$ and $D_{0}$ values, i.e. the distribution coefficients $\left([\mathrm{U}]_{\text {resin }} /[\mathrm{U}]_{\text {solution }}\right)$, in the presence and absence of $\mathrm{HA}$, were derived from supernatant activity measurements. $\beta_{\exp }$ values were calculated using the Schubert relationship, given in equation (viii)

$$
\log \beta_{\text {exp }}=\log _{10} A\left(\frac{D_{0}}{D}-1\right)-n \log [H A]
$$

$A$ is again the side reaction coefficient term, included to take account of competition from hydroxide ions, and $\mathrm{n}$ is the stoichiometric ratio of $\mathrm{HA}$ to $\mathrm{U}(\mathrm{VI})$ in the complex [6]. 


\section{Experimental}

\subsection{Determination of the U(IV)-HA stability constants using the solubility product approach.}

A concentrated solution of BCHA, known to contain traces of carbonate, was taken and purified by addition of hydrochloric acid $\left(5 \mathrm{~mol} \mathrm{dm}^{-3}\right)$, and purged with $\mathrm{N}_{2}$ to remove $\mathrm{CO}_{2}$. The precipitate formed was centrifuged off and dried in a dessicator. A working stock solution was then produced by dissolving the purified $\mathrm{BCHA}$ in dilute carbonate free $\mathrm{NaOH}$ solution. This stock $(904 \mathrm{mg}$ carbon $\mathrm{dm}^{-3}$ ) was successively diluted to produce a range of concentrations. Samples of amorphous $\mathrm{UO}_{2} .2 \mathrm{H}_{2} \mathrm{O}$ were precipitated in NALGENE vials by mixing $2.5 \mathrm{~cm}^{3}$ of carbonate free $\mathrm{NaOH}\left(0.4 \mathrm{~mol} \mathrm{dm}^{-3}\right), 5.0 \mathrm{~cm}^{3} \mathrm{Na}_{2} \mathrm{~S}_{2} \mathrm{O}_{4}$ solution $\left(0.10 \mathrm{~mol} \mathrm{dm}^{-3}\right)$ and $2.5 \mathrm{~cm}^{3} \mathrm{UO}_{2}\left(\mathrm{NO}_{3}\right)_{2}$ solution $\left(0.01 \mathrm{~mol} \mathrm{dm}^{-3}\right.$; containing ${ }^{233} \mathrm{U}$ tracer solution giving $\sim 12 \mathrm{MBq} \mathrm{dm}^{-3}$ ). The solutions were prepared using $\mathrm{N}_{2}$ purged, boiled, de-ionised water and the mixtures were prepared in a $\mathrm{N}_{2}$ atmosphere glove box. After two weeks the aged precipitates were centrifuged, washed with $\mathrm{Na}_{2} \mathrm{~S}_{2} \mathrm{O}_{4}$ solution $\left(0.05 \mathrm{~mol} \mathrm{dm}^{-3}\right)$ and re-centrifuged. The supernatants were then decanted off, and the washed precipitates treated with different amounts of BCHA and AHA. Controls were set up with deionised water and a solution of sodium dithionite $\left(0.01 \mathrm{~mol} \mathrm{dm}^{-3}\right)$ to determine if dithionite was causing a change in the solubility of U(IV). The AHA experiments used AHA diluted to $1000 \mathrm{mg}$ carbon $\mathrm{dm}^{-3}$ with deionised and deoxygenated water and adjusted to the required $\mathrm{pH}$ with $\mathrm{HCl}$ or $\mathrm{NaOH}$. Experiments were performed at $\mathrm{pH}$ values of 8.6, 7.5 and 6.4. The BCHA experiments were designed for multiple repetitions at constant $\mathrm{pH}$ used HEPES buffer $\left(0.1 \mathrm{~mol} \mathrm{dm}^{-3}\right)$. Humic acid addition $\left(\mathrm{x} \mathrm{cm}^{3}\right)$ was followed by $\mathrm{Na}_{2} \mathrm{~S}_{2} \mathrm{O}_{4}$ solution $\left(2.5 \mathrm{~cm}^{3} ; 0.20 \mathrm{~mol} \mathrm{dm}^{-3}\right)$, HEPES buffer $\left(2.5 \mathrm{~cm}^{3}, 0.4 \mathrm{~mol} \mathrm{dm}^{-3}, \mathrm{pH}=8.2\right)$ and sufficient $\mathrm{H}_{2} \mathrm{O}$ to produce a final volume of $10 \mathrm{~cm}^{3}$ i.e. $(5-x) \mathrm{cm}^{3}$.

In the experiments undertaken to determine the solubility product, the HA was omitted. The solutions used in these experiments were filtered through 0.45 , $0.2,0.1,0.02 \mu \mathrm{m}$ and $100 \mathrm{k}, 10 \mathrm{k}$ and $1 \mathrm{k}$ MWCO filters to determine whether $\mathrm{U}(\mathrm{IV})$ colloids were present. After 2 weeks equilibration an aliquot of each supernatant was filtered off ( $0.45 \mathrm{um})$ and the specific activity (d.p.m. $\mathrm{cm}^{-3}$ ) 
determined using liquid scintillation counting (LSC). The $\mathrm{pH}$ and $\mathrm{E}_{\mathrm{h}}$ values were monitored throughout.

\subsection{Determination of the $\mathrm{U}(\mathrm{VI})-\mathrm{BCHA}$ and $\mathrm{U}(\mathrm{VI})$-AHA stability constants using the Schubert ion exchange procedure}

A number of plastic (NALGENE) vials were taken and cation exchanger, in the $\mathrm{Na}$ form, placed in each (10 mg; BioRad AG50W X2; 100-200 mesh). An aliquot $\left(15 \mathrm{~cm}^{3}\right)$ of one of the BCHA solutions was then added, followed by HEPES buffer $\left(5.0 \mathrm{~cm}^{3} ; 0.41 \mathrm{~mol} \mathrm{dm}^{-3} ; \mathrm{pH}=8.0\right)$ and finally ${ }^{233} \mathrm{U}$ tracer solution $\left(0.50 \mathrm{~cm}^{3} ; \sim 6 \mathrm{kBq} \mathrm{cm}{ }^{-3}\right)$. Each vial contained $2.21 \times 10^{-7} \mathrm{~mol} \mathrm{dm}^{-3}$ $\mathrm{U}(\mathrm{VI})$ in $20.5 \mathrm{~cm}^{3}$. A control experiment was also conducted replacing the $\mathrm{BCHA}$ solution with the same volume of water. The resulting mixtures were equilibrated for 2 weeks at room temperature with intermittent shaking. The whole experiment was conducted inside a $\mathrm{N}_{2}$ atmosphere glove box $(<1 \mathrm{ppm}$ $\left.\mathrm{O}_{2}\right)$. Afterwards a filtered $(0.45 \mu \mathrm{m})$ sample of each supernatant was taken $\left(1.0 \mathrm{~cm}^{3}\right)$ and placed in a counting vial, containing $15 \mathrm{~cm}^{3}$ of Ecoscint cocktail. The ${ }^{233} U$ activity was determined using liquid scintillation counting. Quenching problems were avoided by the use of a wide counting channel in which the counting efficiency for ${ }^{233} \mathrm{U}$ was $100 \%$.

The experiments were performed in triplicate. Essential details of the mixtures and the results are given in table 1. A second set of experiments at $\mathrm{pH}=8.4$ was then conducted using acid precipitated AHA instead of BCHA. A similar procedure was followed using a $1000 \mathrm{mg} \mathrm{dm}^{-3}$ purified AHA solution for the initial working stock. The details of the mixtures and results are given in table 2. 


\section{Results and discussion}

\subsection{U(IV) Solubility product determinations}

The calculation of the side reaction coefficient, the A term, is simplified if the dominating uranium species, in the absence of $\mathrm{HA}$, are known at the experimental $\mathrm{pH}$ values. Therefore, calculations were performed using the thermodynamic constants published by Neck and Kim [9] (table 3), to determine the speciation of uranium(IV) from pH 6 to 9. These calculations are shown in figure 1. The calculations were performed using the speciation programme CHESS [10], for an initial concentration of U(IV) of $1 \times 10^{-7} \mathrm{~mol}$ $\mathrm{dm}^{-3}$, which was similar to that used in the experiments. The figure clearly shows that the dominant uranium(IV) species is $\mathrm{U}(\mathrm{OH})_{4}$; which consequently dominates the $\mathrm{A}$ term. The $\mathrm{A}$ term was, therefore, calculated for the $\mathrm{U}^{4+}+$ $4 \mathrm{OH}^{-}=\mathrm{U}(\mathrm{OH})_{4}$ reaction equation using $\log \beta=46$, which was further adjusted to 48.5 to take account of the experimental ionic strength $(I=0.2)$. The required activity coefficients were calculated using the Davies equation [11] i.e. $\log y=-0.51 z^{2}((\sqrt{ } \mathrm{I} /(1+1.5 \sqrt{ } \mathrm{I}))-0.3 \mathrm{I})$, where $\mathrm{I}=$ the ionic strength and $z=$ the charge on the ion.

e.g. at $\mathrm{pH}$ 10.17:

$A=\left\{1+\sum \beta_{4}\left[\mathrm{OH}^{-}\right]^{4}\right\}=1+\left(3.47 \times 10^{48} \times\left(1.48 \times 10^{-4}\right)^{4}\right)=1.66 \times 10^{33}$.

$$
\begin{gathered}
\mathrm{K}_{\mathrm{sp}}=\left[\mathrm{U}^{4+}\right] /\left[\mathrm{OH}^{-}\right]^{4}=[\mathrm{U}]_{\text {solution }}\left[\mathrm{OH}^{-}\right]^{4} / \mathrm{A}=1.52 \times 10^{-8} \times\left(1.48 \times 10^{-4}\right)^{4} / 1.66 \times 10^{33} \\
=4.39 \times 10^{-57}, \text { i.e. } \log \mathrm{K}_{\mathrm{sp}}=-56.4
\end{gathered}
$$

The details and results of the experiments conducted to determine the solubility product of $\mathrm{UO}_{2}(\mathrm{am})$, undertaken in the absence of $\mathrm{HA}$, are summarised in table 4 .

Uranium (IV) oxide solubilities reported in the literature vary [9]. The variation can be attributed to the stoichiometry of the solid and/or its degree of crystallinity. The solubility product determined in this study $\left(\log \mathrm{K}_{\mathrm{sp}}=-56.2\right)$ agrees reasonably well with literature values for amorphous $\mathrm{UO}_{2}$, e.g. $\log \mathrm{K}_{\mathrm{sp}}$ $=-53.45(I=0),-55.7(I=0),-54.5(I=0)[9]$, and $-56.2(I=0),-55.6(I=$ 
3.0), $-54.3(I=0.5)$ [12], which gave confidence in the use of the experimentally determined value to derive the U(IV)-HA $\log \beta$ values.

Control experiments showed that the addition of dithionite $\left(0.01 \mathrm{~mol} \mathrm{dm}^{-3}\right)$ did not increase the solubility of uranium above that which was observed when deionised water alone was added. Hence, the possibility of significant complexation of dithionite with uranium (IV) was discounted. Further control experiments, in which HA free samples were filtered, did not show a decrease in the uranium concentration demonstrating that uranium colloids were not significant.

\subsection{Calculation of the U(IV) - BCHA stability constant}

The U(IV) - BCHA results using the solubility product approach, are shown in Table 5. The presence of $U(I V)$ was assumed based on the $E_{h}$ evidence. The measured $E_{h}$ values may be converted to the standard hydrogen electrode $\left(E_{\text {she }}\right)$ scale by adding $204 \mathrm{mV}$. A term values were calculated using the constants from Neck and Kim [9] (table 1), but modified to be consistent with the ionic strength of the mixtures $(I=0.2)$.

The experiments were conducted at various $\mathrm{pH}$ values. The effect of $\mathrm{pH}$ on the value of $\log B$ is shown in figure 2 . The slope of 4 is a consequence of the dissolution step of $\mathrm{UO}_{2}$ dissolving to form $\mathrm{U}(\mathrm{OH})_{4}$, and the inclusion of this term in the side reaction coefficient. The conditional $\log \beta$ values increased from $26.2 \pm 0.7$ at $\mathrm{pH}=6.9$, to $30.2 \pm 0.8$ at $\mathrm{pH} 7.8$ and $31.2 \pm 0.6$ at $\mathrm{pH} 8.15$. The solubilities of uranium in the presence of $\mathrm{BCHA}$ measured in this study are slightly higher than in [4] for comparable BCHA concentrations. This may be due to differences in the solid phase, i.e. crystalline as against amorphous, and/or the difference between the HA used which may have been caused by the method of preparing the solid $\mathrm{HA}$ and the subsequent solutions. In addition, the BCHA concentrations in the two studies are not exactly the same, and this study was done in the absence of carbonate.

\subsection{U(IV) AHA study}


The U(IV) - AHA results are presented in tables 6, 7 and 8. The conditional $\log \beta$ values were $\log \beta=29.0 \pm 1.3$ at $\mathrm{pH} 8.6, \log \beta=25.6 \pm 1.2$ at $\mathrm{pH} 7.5$ and $\log \beta=21.1 \pm 0.9$ at $\mathrm{pH}$ 6.4. The changes in the $\log \beta$ values with $\mathrm{pH}$ are shown in Figure 3.

\subsection{U(VI) BCHA complexation study at $\mathrm{pH}=\mathbf{8 . 0}$.}

Preliminary experiments were performed using $\mathrm{HCl}$ and $\mathrm{NaOH}$ to produce suitable $\mathrm{pH}$ values. However, $\mathrm{pH}$ control was difficult, so subsequent experiments were performed using HEPES buffer. Comparisons of the two sets of results indicated that the complexation of $\mathrm{U}(\mathrm{VI})$ by humic acid was not affected by the presence of the HEPES buffer. The $\cup_{2}-B C H A$ log $B$ values obtained at $\mathrm{pH}=8.0$ and ionic strength $\mathrm{I}=0.1$, calculated using equation (i), are presented in Table 1. The ionic strength reflected the HEPES concentration. The BCHA concentrations were derived from the total organic carbon (TOC) data supplied with the extract. BCHA was assumed to be comprised of $50 \%$ organic carbon and to possess a $\mathrm{pH}$ independent maximum proton exchange capacity of $4.0 \times 10^{-3} \mathrm{~mol} \mathrm{~g}^{-1}$ [1]. Since carbonate was absent, $\mathrm{U}(\mathrm{VI})$ - carbonato species did not interfere, and the side reaction coefficient $\left(A=4.09 \times 10^{3}\right)$ was calculated using the expression:

$$
A=1+\beta_{\mathrm{UO}_{2}(\mathrm{OH})^{+}}\left[\mathrm{OH}^{-}\right]+\beta_{\mathrm{UO}_{2}(\mathrm{OH})_{2}}\left[\mathrm{OH}^{-}\right]^{2}+\beta_{\mathrm{UO}_{2}(\mathrm{OH})_{3}}\left[\mathrm{OH}^{-}\right]^{3}+\beta_{\mathrm{UO}_{2}\left(\mathrm{OH}_{4}{ }^{2 .}\right.}\left[\mathrm{OH}^{-}\right]^{4}
$$

The $ß$ values for the hydroxy species were derived from the values in the HATCHES [13] database but adjusted, to be consistent with the ionic strength conditions employed in the experiments i.e. $I=0.1$. The final and originally derived values were as follows: $\log \beta_{\mathrm{UO}_{2}(\mathrm{OH})^{+}}=8.32(8.75), \log {\mathrm{UO}_{2}(\mathrm{OH})_{2}}=15.21$ (15.85), $\log ß_{\mathrm{UO}_{2}(\mathrm{OH})_{3}{ }^{-}}=21.1$ (21.75) and $\log ß_{\mathrm{UO}_{2}(\mathrm{OH})_{4}{ }^{2-}}=23.2$ (23.6). The thermodynamic HATCHES values $(I=0)$ are in the brackets. The experiments yielded a mean $\mathrm{UO}_{2}-\mathrm{BCHA} \log ß$ value of 7.93 at $\mathrm{pH}=8.0$ with a standard deviation $=0.33$.

\subsection{Effect of $\mathrm{pH}$ on $\mathrm{U}(\mathrm{VI})$ - BCHA $\log \beta$ values}


Further $\mathrm{U}(\mathrm{VI})$ - $\mathrm{BCHA}$ experiments were conducted, using the same overall approach, but at $\mathrm{pH}$ values of $5.9,7.0,7.2$ and 8.1 still with $\mathrm{I}=0.1$. The $\mathrm{A}$ term values were $2.98,46.5,96.3$ and 7150 respectively. The effect on the resulting $\mathrm{U}(\mathrm{VI})-\mathrm{BCHA}$ constants is displayed graphically in figure 4, the results are in table 9. The log values of the constants increased from 4.42 at $\mathrm{pH} 5.9$ to 5.49 at $\mathrm{pH} 7,5.65$ at $\mathrm{pH} 7.2$ and 7.93 at $\mathrm{pH} 8.1$.

Figure 5 shows the speciation of uranium(VI) in the absence of $\mathrm{HA}$ from $\mathrm{pH} 5$ to 9. The calculations were carried out using the programme CHESS [10]. Over the $\mathrm{pH}$ range used in this study the principle uranium species changes form $\mathrm{UO}_{2}{ }^{2+}$ (aq) to $\mathrm{UO}_{2} \mathrm{OH}^{+}(\mathrm{aq})$ to $\mathrm{UO}_{2}(\mathrm{OH})_{2}{ }^{0}$ (aq) and finally $\mathrm{UO}_{2}(\mathrm{OH})_{3}{ }^{-}(\mathrm{aq})$. The $A$ term, used to calculate the log $\beta$ values reflects this change and as a consequence the stability constant increases with a slope reflecting, but not exactly matching, the number of hydroxide ions involved in the hydrolysis reactions of the $\mathrm{UO}_{2}{ }^{2+}$ ion. A number of other reasons, apart from the conditional nature of the derived log $\beta$ values, have been advanced to explain the increase with pH e.g. (i) unfurling giving access to stronger sites (ii) increasing participation of the phenolic $\mathrm{OH}$ ligands present (iii) increasing formation of mixed hydroxy complexes e.g. $\mathrm{U}(\mathrm{OH})_{x} \mathrm{HA}$, or (iv) increasing electrostatic effects due to the poly-electrolytic properties of HA. Unfortunately the experiments reported here do not provide the evidence needed to distinguish between these possible explanations.

\subsection{U(VI) Aldrich HA complexation study at $\mathrm{pH}=\mathbf{8 . 4}$.}

The U(VI)-AHA results are given in Table 2. The maximum AHA proton exchange capacity was assumed to be $5.3 \times 10^{-3} \mathrm{~mol} \mathrm{~g}^{-1}$ [1] and the A term was calculated to be $1.11 \times 10^{6}$, at $\mathrm{I}=0.1$ and $\mathrm{pH}=8.4$. An average log $\beta$ value of 9.1 with a standard deviation $=0.25$ was obtained. Further experiments, conducted at different $\mathrm{pH}$ values (see below), suggested that the increase in the value reflected the higher $\mathrm{pH}$ of the $\mathrm{AHA}$ experiment rather than intrinsic differences between $U(V I)$ - BCHA and $U(V I)$ - AHA reactions.

The BCHA and AHA Schubert plots based on equation (i) are shown in Figure 6. The observed slopes of approximately one imply 1:1 U(VI) to HA 
stoichiometries, i.e. $n=1$ in equation (i) [5]. The intercepts provided further estimates of the log $\beta$ values $(B C H A=8.94, A H A=9.02)$, but because long extrapolations were involved, means of the individual values were considered to be more reliable. A summary of all the measured $\log \beta$ values is shown in Table 10.

\section{Conclusions}

Under the anaerobic, carbonate free, conditions used the graphically derived $\log \beta$ values for the $\mathrm{BCHA}$ complexes at $\mathrm{pH}=8.2$, were (from Figure 4$) \mathrm{U}(\mathrm{VI})$ $\mathrm{BCHA}=7.91$ (s.d. = 0.39) and (from Figure 2) U(IV)-BCHA = 31.66 (s.d. = 0.33). The AHA constants were generally similar to the $\mathrm{BCHA}$ constants.

Compared with the Schubert approach the solubility product method has certain merits e.g. the complication of the resin solid phase is avoided because the insoluble precipitate itself generates a solid liquid distribution, also the $\mathrm{pH}$ does not have to be controlled only known and the maintenance and measurement of the redox state of the system is facilitated. It is envisaged that the same approach will be used to obtain $\mathrm{Pu}-\mathrm{BCHA}$ constants.

\subsection{Acknowledgement}

Parts of this study was carried out as part of the TRANCOM2 project, which is part funded within the frame of the European Commission's $R \& D$ Programme on the Management and Storage of Radioactive Waste under contract no: FIKW-CT-2000-00008.

\section{6 .0 References.}

[1] A. DIERCKX, M. PUT, P. DE CANNIĖRE, L. WANG, N. MAES, M. AERTSENS, A. MAES, J. VANCLUYSEN, W. VERDICKT, R. GIELEN, M. CHRISTIAENS, P. WARWICK, A. HALL, J. VAN DER LEE, Transport of radionuclides due to complexation with organic matter in clay formations (Trancom - Clay). Nuclear science and Technology series. Luxembourg: Office for Official Publications of the European Communities, EUR 19135 (2000)

[2] T. SAITO, S. NAGASAKI, S. TANAKA, Radiochim. Acta, 90 (2002) 27 
[3] K.R. CZERWINSKI, G. BUCKAU, F. SCHERBAUM, J.I. KIM, Radiochim. Acta 65 (1994) 111

[4] C. CACHOIR, K. LEMMENS S. VAN DEN BERGHE P. VAN ISEGHEM, J Nucl. Materials, 321 (2003) 49

[5] C.J. MILES, J.R. TUSCHALL, P.L. BREZONIK, Anal. Chem., 55 (1983) 410

[6] A. DIERCKX, A. MAES, J. VANCLUYSEN, Radiochim. Acta, 66/67 (1994) 149

[7] A. MAES, J. DE BRABANDERE, A. CREMERS, Radiochim. Acta, 44/45 (1988) 51

[8] I. GRENTHE, I. PUIGDOMENECH (eds), Modelling in Aquatic Chemistry, OECD Publications 1997

[9] V. NECK, J.I. KIM, Radiochim. Acta, 89 (2001) 1

[10] J. VAN DER LEE, CHESS Software for Geochemistry, Hydrology and Environmental Science, École des Mines de Paris, Fontainebleau, France 2002

[11] C.W. DAVIES, Ion association, Butterworths, London 1962

[12] R.M. SMITH, A.E. MARTELL, R.J. MOTEKAITIS, NIST Critically Selected Stability Constants of Metal Complexes Database. (Version 2), US Department of Commerce. Gaithersburg, MD 20899, USA. 1995 [13] T.G. HEATH, HATCHES Database NEA 16, UK Nirex Ltd. 2004 
Table 1. Results of the Schubert experiment, using $\mathrm{Na}$ form cation exchange resin $(10 \mathrm{mg})$, with purified BCHA $\left(15 \mathrm{~cm}^{3}\right.$; proton capacity $\left.4.0 \times 10^{-3} \mathrm{~mol} \mathrm{~g}^{-1}\right)$, HEPES buffer $\left(\mathrm{pH}=8.0 ; 0.41 \mathrm{~mol} \mathrm{dm}^{-3} ; 5.0 \mathrm{~cm}^{3}\right)$ and ${ }^{233} \mathrm{U}$ tracer $\left(0.5 \mathrm{~cm}^{3}\right)$. A $=1.50 \times 10^{5}$.

\begin{tabular}{|c|c|c|c|c|}
\hline $\log [\mathrm{BCHA}]$ & $\begin{array}{l}\text { Supernatant } \\
\text { (d.p.m. } \mathrm{cm}^{-3} \text { ) }\end{array}$ & D & $\log \left(\frac{D_{0}}{D}-1\right) A$ & $\log \beta$ \\
\hline-2.28 & 768.7 & 0.106 & 5.04 & 7.32 \\
\hline-2.58 & 765.1 & 0.111 & 5.02 & 7.60 \\
\hline-2.88 & 713.7 & 0.191 & 4.77 & 7.65 \\
\hline-3.18 & 706.3 & 0.203 & 4.74 & 7.92 \\
\hline-3.48 & 648.5 & 0.311 & 4.54 & 8.02 \\
\hline-4.08 & 526.6 & 0.614 & 4.19 & 8.27 \\
\hline-4.38 & 420.2 & 1.023 & 3.89 & 8.27 \\
\hline-4.99 & 244.8 & 2.472 & 2.90 & 7.88 \\
\hline-5.29 & 222.2 & 2.825 & 2.26 & 7.54 \\
\hline \multicolumn{4}{|c|}{$\begin{array}{l}\text { Total activity present }=850 \text { d.p.m. } \mathrm{cm}^{-3} \\
\mathrm{D}_{\mathrm{o}}=2.95\end{array}$} & $\begin{array}{l}\text { Mean }=7.94 \\
(\text { s.d. }=0.33)\end{array}$ \\
\hline
\end{tabular}


Table 2. Results of the Schubert experiment, using $\mathrm{Na}$ form cation exchange resin $(10 \mathrm{mg})$, with purified AHA $\left(15 \mathrm{~cm}^{3}\right.$; proton capacity $\left.5.3 \times 10^{-3} \mathrm{~mol} \mathrm{~g}^{-1}\right)$, HEPES buffer $\left(\mathrm{pH}=8.4 ; 0.41 \mathrm{~mol} \mathrm{dm}^{-3} ; 5.0 \mathrm{~cm}^{3}\right)$ and ${ }^{233} \mathrm{U} \operatorname{tracer}\left(0.5 \mathrm{~cm}^{3}\right) . \mathrm{D}_{\mathrm{o}}$ $=2.95 ;$ for $\mathrm{A}=4.22 \times 10^{4}$.

\begin{tabular}{|c|c|c|c|c|}
\hline Log[AHA] & $\begin{array}{c}\text { Supernatant } \\
\text { (d.p.m. } \mathbf{~ c m}^{-3} \text { ) }\end{array}$ & $\mathbf{D}$ & $\log \left(\frac{\mathrm{D}_{\mathrm{o}}}{\mathrm{D}}-1\right) \mathrm{A}$ & $\log \boldsymbol{\beta}$ \\
\hline-2.41 & 830.8 & 0.023 & 6.73 & 9.14 \\
\hline-2.71 & 799.9 & 0.063 & 6.29 & 9.00 \\
\hline-3.01 & 717.9 & 0.184 & 5.80 & 8.82 \\
\hline-3.32 & 715.3 & 0.188 & 5.79 & 9.11 \\
\hline-3.62 & 612.7 & 0.387 & 5.45 & 9.06 \\
\hline-3.92 & 557.0 & 0.526 & 5.29 & 9.21 \\
\hline-4.22 & 462.2 & 0.839 & 5.03 & 9.24 \\
\hline-4.52 & 355.2 & 1.393 & 4.67 & 9.19 \\
\hline-4.82 & 313.5 & 1.711 & 4.49 & 9.30 \\
\hline-5.12 & 223.5 & 2.803 & 3.34 & 8.47 \\
\hline-5.42 & 242.7 & 2.502 & 3.88 & 9.30 \\
\hline $\begin{array}{l}\text { Total activity present }=850 \\
\text { D d.p.m. } \mathrm{cm}^{-3}\end{array}$ & $\begin{array}{c}\text { Mean }=9.13 \\
\text { ( s.d. }=0.25)\end{array}$ \\
\hline
\end{tabular}


Table 3. Selected and Estimated Constants for Uranium(IV) Hydroxy Species [9].

\begin{tabular}{|l|c|c|c|}
\hline \multicolumn{1}{|c|}{ Species } & Constant & $\log \boldsymbol{\beta}(\mathbf{2 5} \mathbf{C})(\mathbf{I}=\mathbf{0})$ & $\log \boldsymbol{\beta}(\mathbf{2 5} \mathbf{C})(\mathbf{I}=\mathbf{0 . 2})$ \\
\hline $\mathrm{U}(\mathrm{OH})_{4}(\mathrm{am}) / \mathrm{UO}_{2} . \mathrm{xH}_{2} \mathrm{O}(\mathrm{am})$ & $\log \mathrm{K}_{\mathrm{sp}}$ & $-54.5 \pm 1.0^{*}$ & \\
\hline $\mathrm{UOH}^{3+}$ & $\log \beta_{11}$ & $13.6 \pm 0.2^{\#}$ & 11.1 \\
\hline $\mathrm{U}(\mathrm{OH})_{2}{ }^{2+}$ & $\log \beta_{12}$ & $26.9 \pm 1.0^{\#}$ & 24.4 \\
\hline $\mathrm{U}(\mathrm{OH})_{3}{ }^{+}$ & $\log \beta_{13}$ & $37.3 \pm 1.0^{*}$ & 34.8 \\
\hline $\mathrm{U}(\mathrm{OH})_{4}(\mathrm{aq})$ & $\log \beta_{14}$ & $46.0 \pm 1.4^{*}$ & 43.5 \\
\hline
\end{tabular}

*Selected, \# Estimated 
Table 4 Data for Measurement of Solubility Product of $\mathrm{UO}_{2}(\mathrm{am})$.

\begin{tabular}{|c|c|c|c|c|c|}
\hline $\mathbf{p H}$ & {$[\mathbf{O H}]$} & {$[\mathbf{U}]_{\text {solution }}$} & $\mathbf{A}$ term & $\mathbf{K}_{\text {sp }}$ & ${\text { Log } \mathbf{K}_{\text {sp }}}$ \\
\hline 10.17 & $1.48 \mathrm{E}-04$ & $1.52 \mathrm{E}-08$ & $1.66 \mathrm{E}+33$ & $4.38 \mathrm{E}-57$ & -56.4 \\
\hline 8.90 & $7.94 \mathrm{E}-06$ & $1.95 \mathrm{E}-08$ & $1.38 \mathrm{E}+28$ & $5.62 \mathrm{E}-57$ & -56.3 \\
\hline 10.45 & $2.82 \mathrm{E}-04$ & $7.93 \mathrm{E}-08$ & $2.19 \mathrm{E}+34$ & $2.29 \mathrm{E}-56$ & -55.6 \\
\hline 8.18 & $1.51 \mathrm{E}-06$ & $1.98 \mathrm{E}-08$ & $1.82 \mathrm{E}+25$ & $5.71 \mathrm{E}-57$ & -56.2 \\
\hline 7.04 & $1.10 \mathrm{E}-07$ & $4.94 \mathrm{E}-08$ & $5.02 \mathrm{E}+20$ & $1.42 \mathrm{E}-56$ & -55.8 \\
\hline 6.97 & $9.33 \mathrm{E}-08$ & $1.93 \mathrm{E}-08$ & $2.63 \mathrm{E}+20$ & $5.56 \mathrm{E}-57$ & -56.3 \\
\hline 8.20 & $1.58 \mathrm{E}-06$ & $9.63 \mathrm{E}-09$ & $2.19 \mathrm{E}+25$ & $2.78 \mathrm{E}-57$ & -56.6 \\
\hline & & & & Mean $=$ & -56.2 \\
\hline & & & & S.D. $=$ & 0.31 \\
\hline
\end{tabular}


Table 5. U(IV)-BCHA data and derivation of conditional $\log \beta$ values, using the equilibrium constant expression incorporating the solubility product relationship for $\left[\mathrm{U}^{4+}\right]$.

\begin{tabular}{|c|c|c|c|c|c|c|c|c|c|c|c|}
\hline$[\mathrm{HA}]_{\text {total }}$ & $\log [\mathrm{HA}]$ & $\mathrm{pH}$ & Eh & [OH-] & {$[\mathrm{U}]_{\text {soln }}$} & $\begin{array}{l}{\left[\mathrm{U}^{4+}\right] \text { i.e. }} \\
\mathrm{K}_{\mathrm{sp}} /[\mathrm{OH}]_{4}\end{array}$ & A & [UBCHA] & $\log [\mathrm{UBCHA}]$ & $\beta$ & $\log \beta$ \\
\hline $2.15 E-03$ & -2.67 & 7.84 & -747 & 6.92E-07 & 7.67E-05 & $2.75 \mathrm{E}-32$ & $6.62 \mathrm{E}+18$ & 7.67E-05 & -4.12 & $1.34 \mathrm{E}+30$ & 30.1 \\
\hline $1.08 \mathrm{E}-03$ & -2.97 & 7.83 & -680 & $6.76 \mathrm{E}-07$ & 5.29E-05 & $3.02 \mathrm{E}-32$ & $6.04 \mathrm{E}+18$ & 5.29E-05 & -4.28 & $1.71 E+30$ & 30.2 \\
\hline 4.30E-04 & -3.37 & 7.80 & -652 & 6.31E-07 & 2.64E-05 & $3.98 \mathrm{E}-32$ & $4.58 \mathrm{E}+18$ & 2.64E-05 & -4.58 & $1.64 \mathrm{E}+30$ & 30.2 \\
\hline $3.23 E-04$ & -3.49 & 7.79 & -642 & $6.17 \mathrm{E}-07$ & 4.39E-05 & $4.37 \mathrm{E}-32$ & $4.18 \mathrm{E}+18$ & 4.39E-05 & -4.36 & $3.61 \mathrm{E}+30$ & 30.6 \\
\hline 2.15E-04 & -3.67 & 7.81 & -656 & $6.46 \mathrm{E}-07$ & 7.00E-06 & 3.63E-32 & $5.02 E+18$ & 7.00E-06 & -5.15 & $9.27 E+29$ & 30.0 \\
\hline 1.08E-04 & -3.97 & 7.78 & -653 & 6.03E-07 & 4.62E-06 & 4.79E-32 & $3.81 \mathrm{E}+18$ & $4.62 \mathrm{E}-06$ & -5.34 & $9.38 E+29$ & 30.0 \\
\hline \multirow[t]{3}{*}{$4.30 \mathrm{E}-05$} & -4.37 & 7.79 & -648 & 6.17E-07 & 4.62E-06 & 4.37E-32 & $4.18 \mathrm{E}+18$ & $4.62 \mathrm{E}-06$ & -5.34 & $2.76 \mathrm{E}+30$ & 30.4 \\
\hline & Mean $=$ & 7.81 & & & & & & & & Mean $=$ & 30.2 \\
\hline & & & & & & & & & & S.D. $=$ & 0.22 \\
\hline 4.30E-05 & -4.37 & 8.20 & -688 & 1.58E-06 & 5.10E-06 & $1.00 \mathrm{E}-33$ & $1.82 \mathrm{E}+20$ & $5.10 \mathrm{E}-06$ & -5.29 & $1.35 E+32$ & 32.1 \\
\hline 1.08E-04 & -3.97 & 8.13 & -687 & 1.35E-06 & 7.19E-06 & 1.91E-33 & $9.55 E+19$ & 7.19E-06 & -5.14 & $3.76 E+31$ & 31.6 \\
\hline $2.15 \mathrm{E}-04$ & -3.67 & 8.11 & -684 & $1.29 \mathrm{E}-06$ & 7.19E-06 & $2.29 \mathrm{E}-33$ & $7.95 \mathrm{E}+19$ & 7.19E-06 & -5.14 & $1.51 \mathrm{E}+31$ & 31.2 \\
\hline 4.30E-04 & -3.37 & 8.09 & -680 & 1.23E-06 & 9.89E-06 & 2.75E-33 & $6.61 \mathrm{E}+19$ & 9.89E-06 & -5.00 & $8.55 E+30$ & 30.9 \\
\hline $2.15 E-03$ & -2.67 & 8.14 & -681 & 1.38E-06 & 1.12E-05 & 1.74E-33 & $1.05 E+20$ & 1.12E-05 & -4.95 & $3.01 \mathrm{E}+30$ & 30.5 \\
\hline $2.15 \mathrm{E}-03$ & -2.67 & 8.18 & -693 & $1.51 \mathrm{E}-06$ & 3.52E-05 & 1.20E-33 & $1.51 \mathrm{E}+20$ & 3.52E-05 & -4.45 & $1.38 E+31$ & 31.1 \\
\hline \multirow[t]{3}{*}{$2.15 \mathrm{E}-03$} & -2.67 & 8.18 & -701 & 1.51E-06 & 2.29E-05 & $1.20 \mathrm{E}-33$ & $1.51 \mathrm{E}+20$ & 2.29E-05 & -4.64 & $8.94 \mathrm{E}+30$ & 31.0 \\
\hline & Mean $=$ & 8.15 & & & & & & & & Mean $=$ & 31.2 \\
\hline & & & & & & & & & & S.D. $=$ & 0.56 \\
\hline 2.69E-04 & -3.57 & 7.04 & -621 & 1.10E-07 & 1.08E-05 & 4.37E-29 & $4.25 E+15$ & 1.08E-05 & -4.97 & $9.59 E+26$ & 27.0 \\
\hline
\end{tabular}




\begin{tabular}{|c|c|c|c|c|c|c|c|c|c|c|c|}
\hline 2.69E-04 & -3.57 & 7.04 & -583 & 1.10E-07 & 9.85E-06 & 4.37E-29 & $4.25 E+15$ & 9.85E-06 & -5.01 & $8.72 E+26$ & 26.9 \\
\hline 5.38E-04 & -3.27 & 6.97 & -607 & 9.33E-08 & 1.34E-05 & 8.32E-29 & $2.24 \mathrm{E}+15$ & 1.34E-05 & -4.87 & $3.07 E+26$ & 26.5 \\
\hline 5.38E-04 & -3.27 & 6.97 & -612 & 9.33E-08 & 1.25E-05 & 8.32E-29 & $2.24 \mathrm{E}+15$ & $1.25 \mathrm{E}-05$ & -4.90 & $2.86 \mathrm{E}+26$ & 26.5 \\
\hline 1.08E-03 & -2.97 & 6.87 & -614 & 7.41E-08 & 1.28E-05 & $2.09 E-28$ & $8.95 E+14$ & 1.28E-05 & -4.89 & $5.77 E+25$ & 25.8 \\
\hline 1.08E-03 & -2.97 & 6.87 & -599 & 7.41E-08 & 1.29E-05 & 2.09E-28 & $8.95 E+14$ & 1.29E-05 & -4.89 & $5.81 \mathrm{E}+25$ & 25.8 \\
\hline $2.15 \mathrm{E}-03$ & -2.67 & 6.78 & -604 & $6.03 E-08$ & 1.63E-05 & 4.79E-28 & $3.93 E+14$ & 1.63E-05 & -4.79 & $1.60 \mathrm{E}+25$ & 25.2 \\
\hline \multirow[t]{3}{*}{$2.15 \mathrm{E}-03$} & -2.67 & 6.78 & -622 & 6.03E-08 & 1.57E-05 & 4.79E-28 & $3.93 E+14$ & 1.57E-05 & -4.80 & $1.54 \mathrm{E}+25$ & 25.2 \\
\hline & Mean = & 6.90 & & & & & & & & Mean $=$ & 26.2 \\
\hline & & & & & & & & & & S.D. $=$ & 0.67 \\
\hline
\end{tabular}


Table 6. U(IV)-AHA data at $\mathrm{pH} 8.4$ and derivation of conditional log $\beta$ values, using the equilibrium constant expression incorporating the solubility product relationship for $\left[\mathrm{U}^{4+}\right]$.

\begin{tabular}{|c|c|c|c|c|c|c|c|c|c|c|c|}
\hline [HA] molar & $\log [\mathrm{HA}]$ & $\mathrm{pH}$ & DPM & {$[U]_{\text {total }}$} & {$[\mathrm{OH}]$} & {$\left[\mathrm{U}^{4+}\right]$} & A Term & [UHA] & $\log [\mathrm{UHA}]$ & $\beta$ & $\log \beta$ \\
\hline $2.65 \mathrm{E}-03$ & -2.58 & 8.23 & \begin{tabular}{|l|}
882.1 \\
\end{tabular} & $8.76 \mathrm{E}-06$ & 1.70E-06 & $3.13 \mathrm{E}-31$ & $2.40 \mathrm{E}+20$ & $8.76 \mathrm{E}-06$ & -5.06 & $1.06 \mathrm{E}+28$ & 28.0 \\
\hline $2.65 \mathrm{E}-03$ & -2.58 & 8.51 & 834.8 & $9.35 \mathrm{E}-06$ & $3.24 \mathrm{E}-06$ & $2.37 \mathrm{E}-$ & $3.16 \mathrm{E}+21$ & $9.35 \mathrm{E}-06$ & -5.03 & 1.49E+29 & 29.2 \\
\hline $2.65 \mathrm{E}-03$ & -2.58 & 8.78 & 891.9 & & & & $100--$ & $9.99 \mathrm{E}-06$ & -5.00 & $1.92 \mathrm{E}+30$ & 30.3 \\
\hline 1.33E-03 & -2.88 & 8.12 & 513.5 & & 132 & 10 & $871 \mathrm{~F}-$ & $5.75 \mathrm{E}-06$ & -5.24 & $5.07 \mathrm{E}+27$ & 27.7 \\
\hline $1.33 \mathrm{E}-03$ & -2.88 & 8.42 & \begin{tabular}{|l|}
610.4 \\
\end{tabular} & $6.84 \mathrm{E}$ & $2.63 \mathrm{E}$ & $5.43 \mathrm{E}$ & $1.38 \mathrm{E}+$ & $6.84 \mathrm{E}-06$ & -5.16 & $9.55 \mathrm{E}+28$ & 29.0 \\
\hline $1.33 \mathrm{E}-03$ & -2.88 & 8.92 & 425.8 & 4.77E-06 & 8.32E-06 & $5.43 \mathrm{E}-34$ & $1.38 \mathrm{E}+23$ & $4.77 \mathrm{E}-06$ & -5.32 & $6.65 \mathrm{E}+30$ & 30.8 \\
\hline $1.33 \mathrm{E}-03$ & -2.88 & 8.30 & 333.0 & $3.73 \mathrm{E}-06$ & $2.00 \mathrm{E}-06$ & $1.64 \mathrm{E}-31$ & $4.57 \mathrm{E}+20$ & $3.73 \mathrm{E}-06$ & -5.43 & $1.72 \mathrm{E}+28$ & 28.2 \\
\hline 5.30 & -3.28 & 8.17 & 187.88 & $3.1^{1}$ & 1.4 & $5.43 E-31$ & 1.38 & -06 & -5.68 & $7.34 \mathrm{E}+27$ & 27.9 \\
\hline $5.30 \mathrm{E}-04$ & -3.28 & 8.78 & 196.99 & 2.2 & 6.0 & $1.97 \mathrm{E}-33$ & 3.80 & -06 & -5.6 & $2.12 \mathrm{E}+30$ & 30.3 \\
\hline $5.30 \mathrm{E}-04$ & -3.28 & 8.43 & 142.77 & \begin{tabular}{l|l}
$71.60 \mathrm{E}-06$ \\
\end{tabular} & $2.69 \mathrm{E}-0$ & $4.95 \mathrm{E}-\mathrm{a}$ & $1.51 \mathrm{E}+21$ & $1.60 \mathrm{E}-06$ & -5.80 & $6.11 \mathrm{E}+28$ & 28.8 \\
\hline $3.98 \mathrm{E}-04$ & -3.40 & 8.92 & 19.87 & $2.23 \mathrm{E}-07$ & $8.32 \mathrm{E}-06$ & $5.43 \mathrm{E}-34$ & $1.38 \mathrm{E}+23$ & 2.23E-07 & -6.65 & $1.03 \mathrm{E}+30$ & 30.0 \\
\hline $3.98 \mathrm{E}-04$ & -3.40 & 8.33 & 12.91 & 1.45E-07 & $2.14 \mathrm{E}-06$ & $1.24 \mathrm{E}-31$ & $6.02 \mathrm{E}+20$ & 1.45E-07 & -6.84 & $2.92 \mathrm{E}+27$ & 27.5 \\
\hline 3.9 & -3.40 & 8.42 & & & & & & $4.11 \mathrm{E}-07$ & -6.39 & $1.90 \mathrm{E}+28$ & 28.3 \\
\hline 3.98 & -3 & 8.52 & & & & & 3.4 & & 5 & +28 & 28.6 \\
\hline 2.65E-04 & -3.58 & 8.37 & 99 & 1.53 & 2.3 & $8.61 \mathrm{E}-3$ & 8.71 & $1.53 \mathrm{E}-07$ & -6.81 & $6.73 \mathrm{E}+27$ & 27.8 \\
\hline $2.65 \mathrm{E}-04$ & -3.58 & 8.50 & 13.82 & $1.55 \mathrm{E}-07$ & $3.16 \mathrm{E}-06$ & $2.60 \mathrm{E}-32$ & $2.88 \mathrm{E}+21$ & $1.55 \mathrm{E}-07$ & -6.81 & $2.25 \mathrm{E}+28$ & 28.4 \\
\hline $2.65 \mathrm{E}-04$ & -3.58 & 8.70 & 10.96 & $1.23 \mathrm{E}-07$ & $5.01 \mathrm{E}-06$ & $4.12 \mathrm{E}-33$ & $1.82 \mathrm{E}+22$ & $1.23 \mathrm{E}-07$ & -6.91 & $1.12 \mathrm{E}+29$ & 29.1 \\
\hline $2.65 \mathrm{E}-04$ & -3.58 & 8.70 & 18.91 & 9.99E-08 & $5.01 \mathrm{E}-06$ & $4.12 \mathrm{E}-33$ & $1.82 \mathrm{E}+22$ & $9.98 \mathrm{E}-08$ & -7.00 & $9.14 \mathrm{E}+28$ & 29.0 \\
\hline 2.65E-04 & -3.58 & 8.31 & 18.57 & $9.61 \mathrm{E}-08$ & & 505 & & $9.60 \mathrm{E}-08$ & -7.02 & $2.42 \mathrm{E}+27$ & 27.4 \\
\hline & -3. & 8.73 & 4.52 & & & -3 & 2.4 & 08 & -7.30 & +29 & 29.1 \\
\hline & & .05 & & & & & & & -1.23 & $+\angle$ & 20.0 \\
\hline
\end{tabular}




\begin{tabular}{|c|c|c|c|c|c|c|c|c|}
\hline 1.33E-04 & -3.88 & 8.44 & 2.64 & \begin{tabular}{|l|l|l|}
$2.96 \mathrm{E}-08$ & $2.75 \mathrm{E}-06$ & $4.52 \mathrm{E}-32$ \\
\end{tabular} & 1.66E+21 2.95E-08 & -7.53 & $4.94 E+27$ & 27.7 \\
\hline $1.33 E-04$ & -3.88 & 8.58 & 3.87 & \begin{tabular}{|c|c|c|} 
4.34E-08 $3.80 \mathrm{E}-06$ & $1.24 \mathrm{E}-32$ \\
\end{tabular} & $6.02 E+214.33 E-08$ & -7.36 & $2.63 E+28$ & 28.4 \\
\hline 1.33E-04 & -3.88 & 8.84 & 7.14 & 8.00E-08 6.92E-06 1.13E-33 & $6.60 \mathrm{E}+228.00 \mathrm{E}-08$ & -7.10 & $5.32 E+29$ & 29.7 \\
\hline 5.30E-05 & -4.28 & 8.39 & 6.41 & 7.19E-08 2.45E-06 7.16E-32 & $1.05 \mathrm{E}+217.18 \mathrm{E}-08$ & -7.14 & $1.89 \mathrm{E}+28$ & 28.3 \\
\hline 5.30E-05 & -4.28 & 8.86 & 7.96 & 8.92E-08 7.24E-06 9.44E-34 & $7.93 \mathrm{E}+228.91 \mathrm{E}-08$ & -7.05 & $1.78 \mathrm{E}+30$ & 30.3 \\
\hline 5.30E-05 & -4.28 & 8.30 & 3.26 & 3.66E-08 2.00E-06 1.64E-31 & $4.57 \mathrm{E}+203.65 \mathrm{E}-08$ & -7.44 & $4.20 \mathrm{E}+27$ & 27.6 \\
\hline 5.30E-05 & -4.28 & 8.45 & 4.09 & 4.59E-08 $2.82 \mathrm{E}-06$ 4.12E-32 & $1.82 \mathrm{E}+214.58 \mathrm{E}-08$ & -7.34 & $2.10 \mathrm{E}+28$ & 28.3 \\
\hline Mean & & 8.58 & & $9.43 E-32$ & 1.98E-06 & & & 29.7 \\
\hline S.D. & & 0.32 & & 1.84E-31 & $3.10 \mathrm{E}-06$ & & & 1.32 \\
\hline
\end{tabular}


Table 7. U(IV)-AHA data at $\mathrm{pH} 7.4$ and derivation of conditional log $\beta$ values, using the equilibrium constant expression incorporating the solubility product relationship for $\left[\mathrm{U}^{4+}\right]$.

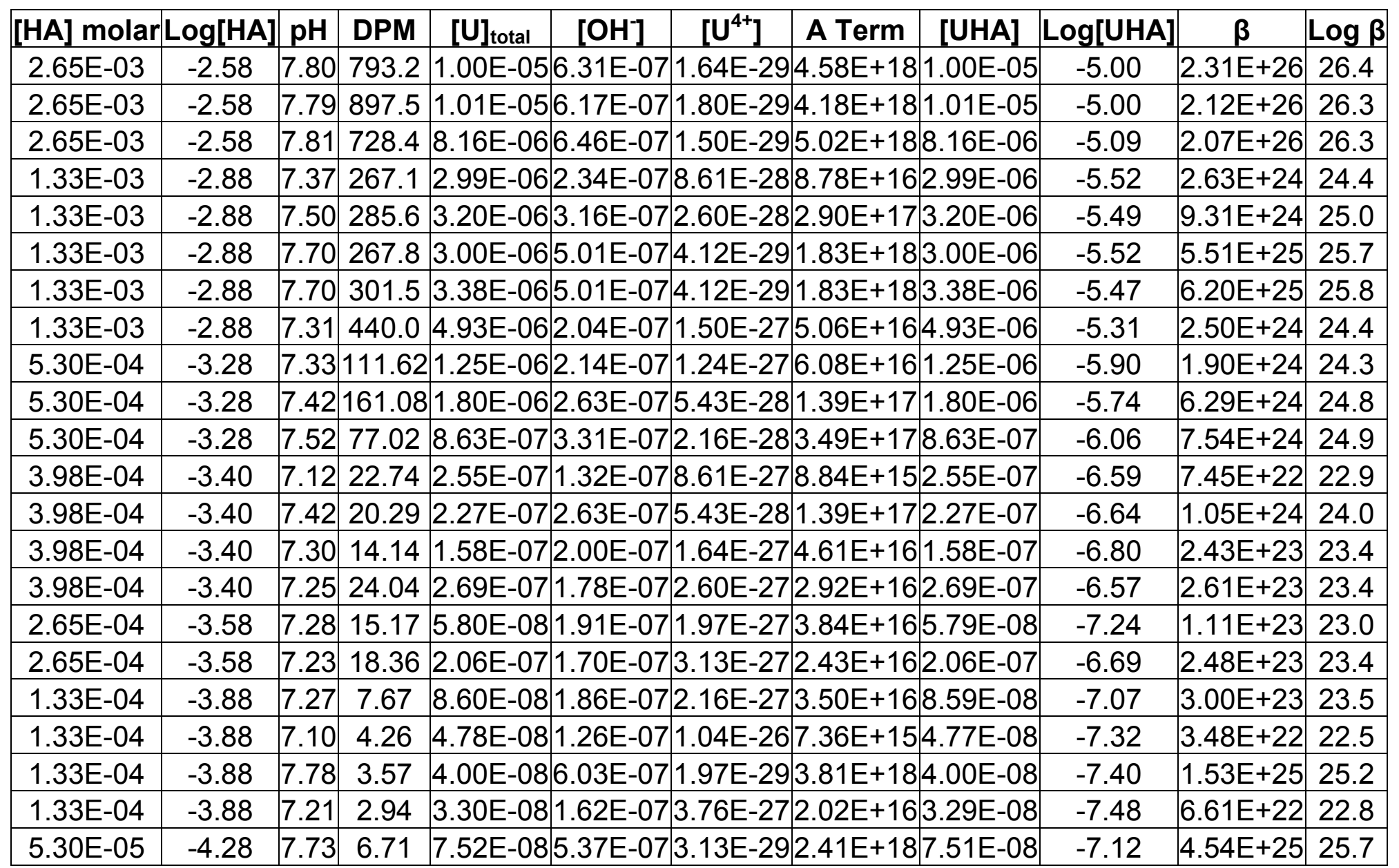




\begin{tabular}{|c|r|r|r|r|r|r|r|}
\hline Mean & 7.45 & & $1.80 \mathrm{E}-27$ & $2.32 \mathrm{E}-06$ & & 25.6 \\
\hline S.D. & 0.24 & & $2.74 \mathrm{E}-27$ & $3.23 \mathrm{E}-06$ & & & 1.23 \\
\hline
\end{tabular}


Table 8. U(IV)-AHA data at $\mathrm{pH} 6.4$ and derivation of conditional log $\beta$ values, using the equilibrium constant expression incorporating the solubility product relationship for $\left[\mathrm{U}^{4+}\right]$.

\begin{tabular}{|c|c|c|c|c|c|c|c|c|c|c|c|}
\hline$[\mathrm{HA}]$ & [HA] & $\mathrm{pH}$ & DPM & {$[\mathrm{U}]_{\text {total }}$} & {$[\mathrm{OH}]$} & {$\left[\mathrm{U}^{4+}\right]$} & A Term & [UHA] & $\log [\mathrm{UHA}]$ & $\beta$ & $\log \beta$ \\
\hline 2.65E-03 & -2.58 & 6.63 & 724 & $8.12 \mathrm{E}-06$ & 4.27E- & $85 \mathrm{E}-2$ & 1.00E+14 & $3.12 \mathrm{E}-06$ & -5.09 & $3.91 \mathrm{E}+21$ & 121.6 \\
\hline $2.65 \mathrm{E}-03$ & -2.58 & 6 & & 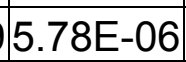 & 3.16 & $60 \mathrm{~B}$ & & & 24 & $8.41 E+20$ & 20.9 \\
\hline E-03 & -2.58 & 6.30 & & $6.89 \mathrm{E}-$ & 2.0 & $1.64 \mathrm{E}-23$ & 5.07E+ & 06 & 16 & $1.59 E+20$ & 20.2 \\
\hline E-03 & -2.88 & 6. & & 2 & & & & & & $2.24 \mathrm{E}+20$ & 20.4 \\
\hline$E-03$ & -2.88 & 6.69 & & $2.01 \mathrm{E}-06$ & 4.9 & $4.52 \mathrm{E}$ & $1.73 \mathrm{E}+$ & 06 & 70 & $3.36 E+21$ & \begin{tabular}{|l|l|} 
& 21.5 \\
\end{tabular} \\
\hline & -2.88 & 6.0 & & 2.2 & 1.2 & 27 & 7 & -06 & & $1.39 \mathrm{E}+19$ & \begin{tabular}{|l|l|}
9 & 19.1 \\
\end{tabular} \\
\hline-03 & -2.88 & 6.67 & & $1.25 \mathrm{E}-06$ & 4.6 & $5.43 E-25$ & $1.44 \mathrm{E}+$ & $=-06$ & -5.90 & $1.74 \mathrm{E}+21$ & \begin{tabular}{|l|l|}
11.2 \\
\end{tabular} \\
\hline & & 6.1 & & 8.5 & 1 & 31 & & & -6.07 & $2.48 \mathrm{E}+19$ & \begin{tabular}{|l|l|}
9 & 19.4 \\
\end{tabular} \\
\hline 5.3 & -3.28 & 6.1 & & 1.0 & 1.2 & .04 & 8 & -06 & -5.97 & $1.96 \mathrm{E}+19$ & \begin{tabular}{|l|l|}
9 & 19.3 \\
\end{tabular} \\
\hline 04 & & 6.4 & & E-06 & 2.6 & $5.43 E-24$ & 1 & 06 & -5.96 & $3.84 \mathrm{E}+20$ & 20.6 \\
\hline 04 & -3.28 & 6.1 & & 1.1 & 1.3 & 8.6 & 1 & $=-06$ & -5.96 & $2.41 \mathrm{E}+19$ & \begin{tabular}{|l|l|}
9 & 19.4 \\
\end{tabular} \\
\hline 04 & -3.28 & 6.77 & & $E-06$ & 5.8 & $2.16 \mathrm{E}-25$ & 3.5 & & -5.96 & $9.53 E+21$ & \begin{tabular}{|l|l|}
122.0 \\
\end{tabular} \\
\hline 3.9 & -3.40 & 6.38 & & 2.5 & 2.4 & 3.85 & 1 & E-07 & -6.60 & $8.05 E+19$ & \begin{tabular}{|l|l|}
9 & 19.9 \\
\end{tabular} \\
\hline 04 & -3.40 & 6.68 & & E-07 & 4.7 & 4.95E-25 & $E+14$ & -07 & -6.67 & $1.09 \mathrm{E}+21$ & \begin{tabular}{|l|l|}
1 & 21.0 \\
\end{tabular} \\
\hline 3.9 & -3.40 & 6.03 & & 2.0 & 1.0 & 24 & & & -6.70 & $2.57 \mathrm{E}+18$ & \begin{tabular}{|l|l|}
3 & 18.4 \\
\end{tabular} \\
\hline 2.6 & -3.58 & 6.58 & 17.09 & $E-07$ & 3.8 & $1.24 \mathrm{E}-24$ & $E+13$ & 07 & -6.72 & $5.81 \mathrm{E}+20$ & 20.8 \\
\hline & & 6.48 & & $2.04 \mathrm{E}-07$ & 3.0 & $3.13 E-24$ & $2.57 \mathrm{E}+$ & 07 & -6.69 & $2.46 E+20$ & 20.4 \\
\hline-04 & -3.58 & 6.58 & 13 & -07 & 3.8 & 1.24E-24 & $E+13$ & E-07 & -6.82 & $4.57 \mathrm{E}+20$ & 20.7 \\
\hline & -3.88 & 6.72 & 4.42 & 4.96E-08 & 5.2 & $3.43 E-25$ & $2.28 \mathrm{E}+14$ & 4.95E-08 & -7.31 & $1.09 \mathrm{E}+21$ & 121.0 \\
\hline 5.30E-05 & -4.28 & 6.39 & 4.02 & $4.50 \mathrm{E}-08$ & 2.4 & $7.16 \mathrm{E}-24$ & $\mathrm{E}+13$ & 4.50E-08 & -7.35 & 1.19E+20 & 20.1 \\
\hline Mean & & 6.43 & & & & $3.20 \mathrm{E}-23$ & & 1.89E-06 & & & 21.1 \\
\hline S.D. & & 0.24 & & & & $5.47 E-23$ & & 2.47E-06 & & & 0.93 \\
\hline
\end{tabular}


Table 9. Data for $\mathrm{U}(\mathrm{VI}) \mathrm{BCHA}$ Stability Constant Measurements at Various $\mathrm{pHs}$

\begin{tabular}{|c|c|c|c|c|c|}
\hline$[\mathrm{HA}] \mathrm{mol} \mathrm{dm}^{-3}$ & d.p.m. & D & A Term & $\log \left(\frac{D_{0}}{D}-1\right) A$ & $\log \beta$ \\
\hline 2.14E-03 & 600.0 & 0.417 & 2.98 & 1.26 & 3.93 \\
\hline 1.07E-03 & 741.0 & 0.147 & 2.98 & 1.75 & 4.72 \\
\hline $5.25 E-04$ & 520.2 & 0.634 & 2.98 & 1.04 & 4.32 \\
\hline $2.63 \mathrm{E}-04$ & 426.2 & 0.994 & 2.98 & 0.77 & 4.35 \\
\hline 1.32E-04 & 361.2 & 1.353 & 2.98 & 0.55 & 4.43 \\
\hline \multirow[t]{2}{*}{$6.61 \mathrm{E}-05$} & 300.4 & 1.830 & 2.98 & 0.26 & 4.44 \\
\hline & & & & Mean $=$ & 4.42 \\
\hline $\mathrm{pH}=5.9$ & & & & s.d. $=$ & 0.26 \\
\hline 1.91E-03 & 645.7 & 0.316 & 46.5 & 2.59 & 5.31 \\
\hline $9.55 E-04$ & 604.3 & 0.407 & 46.5 & 2.46 & 5.48 \\
\hline 4.79E-04 & 524.7 & 0.620 & 46.5 & 2.24 & 5.56 \\
\hline $2.40 \mathrm{E}-04$ & 425.1 & 0.999 & 46.5 & 1.96 & 5.58 \\
\hline 1.17E-04 & 346.7 & 1.452 & 46.5 & 1.68 & 5.61 \\
\hline \multirow[t]{2}{*}{$5.89 \mathrm{E}-05$} & 255.6 & 2.325 & 46.5 & 1.10 & 5.33 \\
\hline & & & & Mean $=$ & 5.49 \\
\hline $\mathrm{pH}=7$ & & & & s.d. $=$ & 0.13 \\
\hline $1.86 \mathrm{E}-03$ & 583.3 & 0.457 & 96.3 & 2.72 & 5.45 \\
\hline $9.33 E-04$ & 514.4 & 0.652 & 96.3 & 2.53 & 5.56 \\
\hline $4.68 \mathrm{E}-04$ & 471.3 & 0.804 & 96.3 & 2.41 & 5.74 \\
\hline $2.34 \mathrm{E}-04$ & 340.3 & 1.498 & 96.3 & 1.97 & 5.60 \\
\hline $1.15 \mathrm{E}-04$ & 249.0 & 2.414 & 96.3 & 1.33 & 5.27 \\
\hline \multirow[t]{2}{*}{$5.75 \mathrm{E}-05$} & 292.2 & 1.909 & 96.3 & 1.72 & 5.96 \\
\hline & & & & Mean $=$ & 5.65 \\
\hline $\mathrm{pH}=7.2$ & & & & s.d. = & 0.24 \\
\hline $3.80 \mathrm{E}-03$ & 800.6 & 0.062 & 7150 & 5.52 & 7.94 \\
\hline 1.91E-03 & 645.7 & 0.316 & 7150 & 4.77 & 7.49 \\
\hline $9.55 E-04$ & 664.3 & 0.279 & 7150 & 4.83 & 7.85 \\
\hline $4.79 \mathrm{E}-04$ & 523.0 & 0.625 & 7150 & 4.42 & 7.74 \\
\hline $2.40 \mathrm{E}-04$ & 455.1 & 0.868 & 7150 & 4.23 & 7.85 \\
\hline 1.17E-04 & 409.2 & 1.077 & 7150 & 4.09 & 8.02 \\
\hline $5.89 \mathrm{E}-05$ & 360.8 & 1.356 & 7150 & 3.92 & 8.15 \\
\hline $2.95 \mathrm{E}-05$ & 241.4 & 2.522 & 7150 & 3.08 & 7.61 \\
\hline 4.27E-03 & 802.7 & 0.059 & 7150 & 5.54 & 7.91 \\
\hline
\end{tabular}




\begin{tabular}{|c|c|c|c|c|c|}
\hline $2.14 \mathrm{E}-03$ & 725.7 & 0.171 & 7150 & 5.06 & 7.73 \\
\hline $1.07 \mathrm{E}-03$ & 616.0 & 0.380 & 7150 & 4.68 & 7.65 \\
\hline $5.25 \mathrm{E}-04$ & 515.7 & 0.648 & 7150 & 4.40 & 7.68 \\
\hline $2.63 \mathrm{E}-04$ & 469.0 & 0.812 & 7150 & 4.27 & 7.85 \\
\hline $6.61 \mathrm{E}-05$ & 321.5 & 1.644 & 7150 & 3.75 & 7.93 \\
\hline $3.31 \mathrm{E}-05$ & 268.7 & 2.164 & 7150 & 3.41 & 7.89 \\
\hline $8.32 \mathrm{E}-06$ & 216.9 & 2.918 & 7150 & 1.89 & 6.97 \\
\hline $4.17 \mathrm{E}-06$ & 250.8 & 2.390 & 7150 & 3.22 & 8.60 \\
\hline & & & & Mean $=$ & 7.93 \\
\hline $\mathrm{pH}=8.1$ & & & & s.d. $=$ & 0.46 \\
\hline
\end{tabular}


Table 10. Summary of $\log \beta$ values.

\begin{tabular}{|c|l|l|l|}
\hline Humic & $\mathbf{p H}$ & $\mathbf{U}(\mathbf{I V}) \log \boldsymbol{\mathbf { }}(\mathbf{V I}) \log \boldsymbol{\beta}$ \\
\hline BCHA & 8.0 & & $7.94 \pm 0.33$ \\
\hline AHA & 8.4 & & $9.13 \pm 0.25$ \\
\hline BCHA & 5.9 & & $4.42 \pm 0.26$ \\
\hline BCHA & 7.0 & & $5.49 \pm 0.13$ \\
\hline BCHA & 7.2 & & $5.65 \pm 0.24$ \\
\hline BCHA & 8.1 & & $7.93 \pm 0.46$ \\
\hline BCHA & 7.8 & $30.2 \pm 0.22$ & \\
\hline BCHA & 8.2 & $31.2 \pm 0.56$ & \\
\hline BCHA & 6.9 & $26.2 \pm 0.67$ & \\
\hline AHA & 8.6 & $29.7 \pm 1.32$ & \\
\hline AHA & 7.5 & $25.6 \pm 1.23$ & \\
\hline AHA & 6.4 & $21.1 \pm 0.93$ & \\
\hline
\end{tabular}


P. Warwick Figure 1. Speciation of Uranium(IV) from $\mathrm{pH} 6$ to 9.

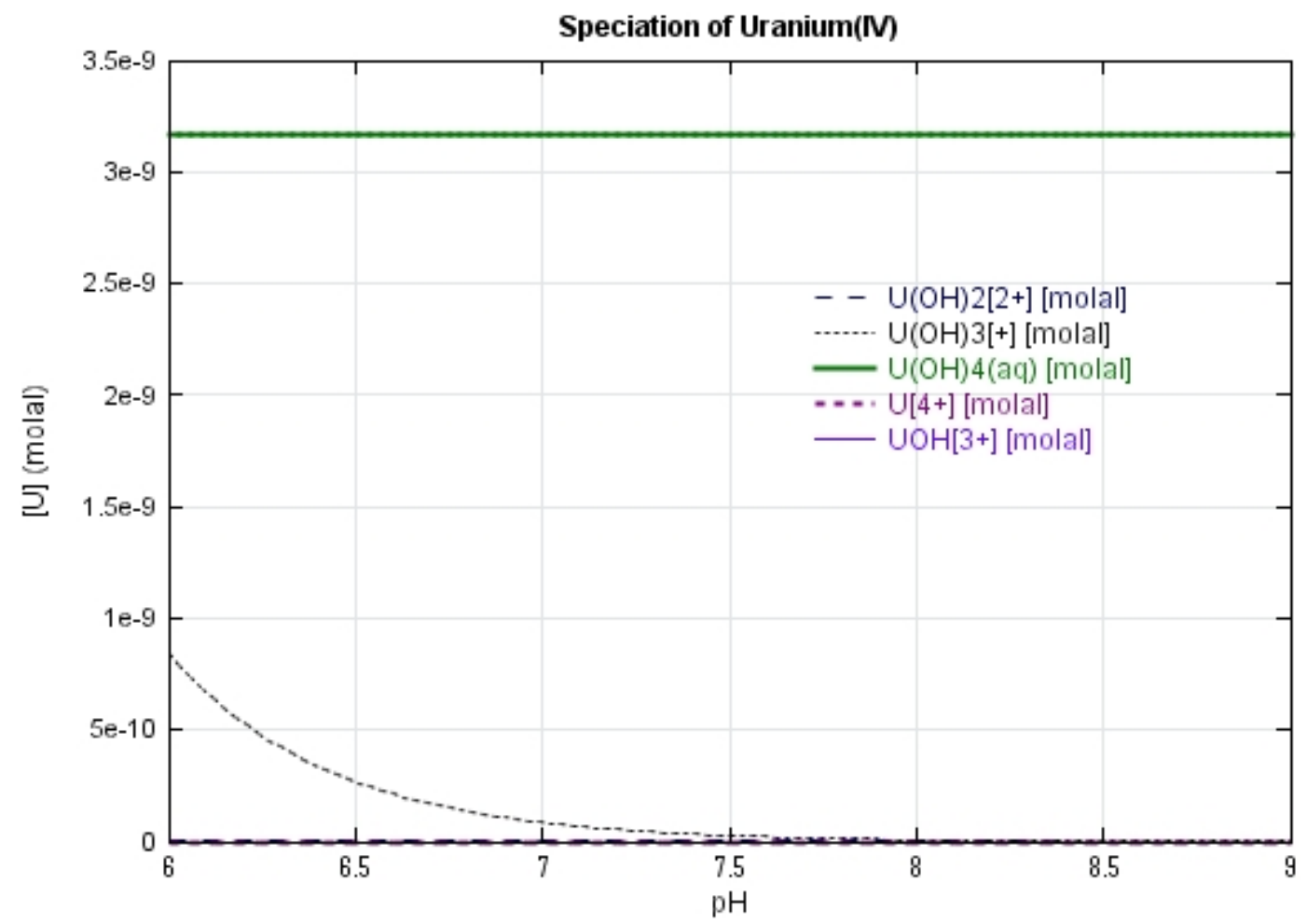


P. Warwick Figure 2. Variation of U(IV)-BCHA $\log \beta$ values with $\mathrm{pH}$.

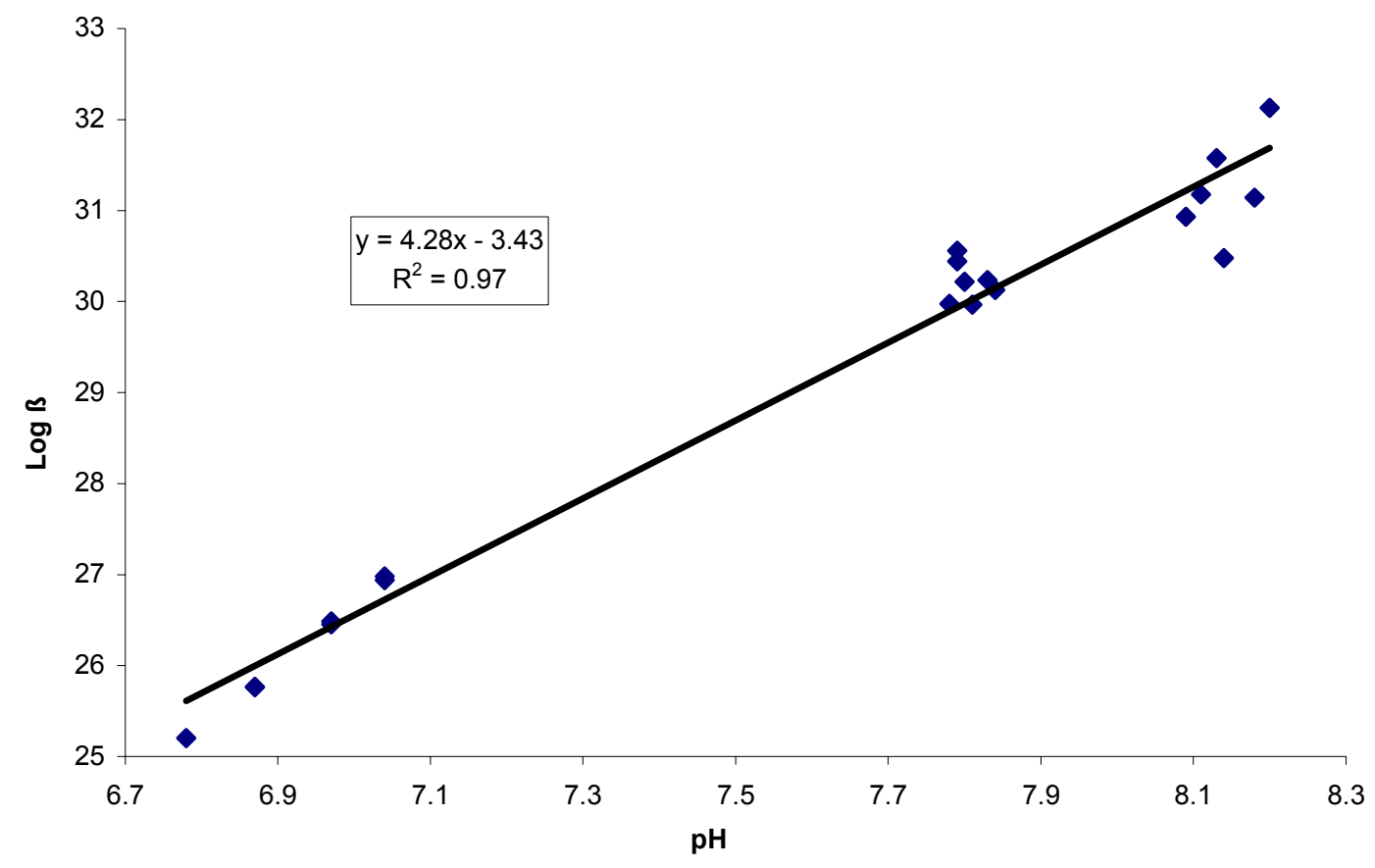


P. Warwick Figure 3. Variation of U(IV)-AHA $\log \beta$ values with $\mathrm{pH}$.

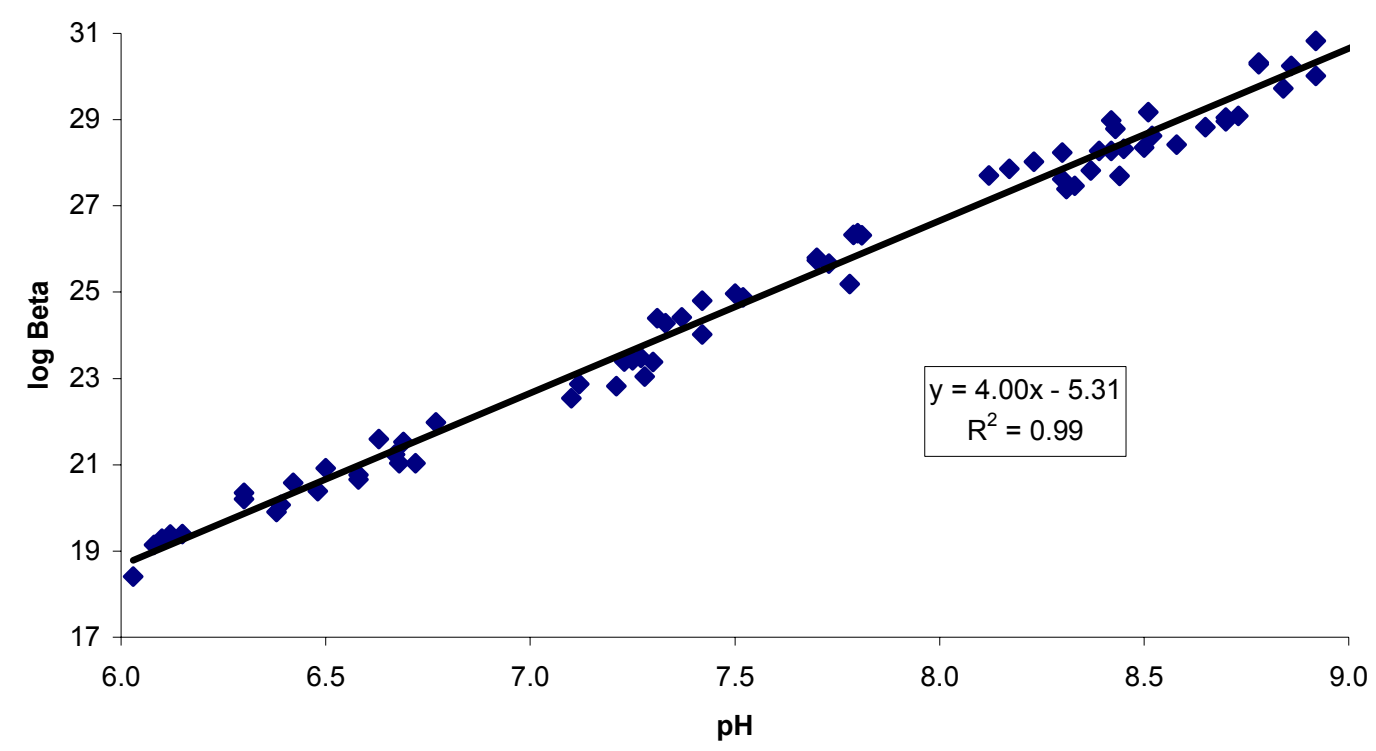


P. Warwick Figure 4. Variation of $\mathrm{U}(\mathrm{VI})-\mathrm{BCHA} \log \beta$ values with $\mathrm{pH}$.

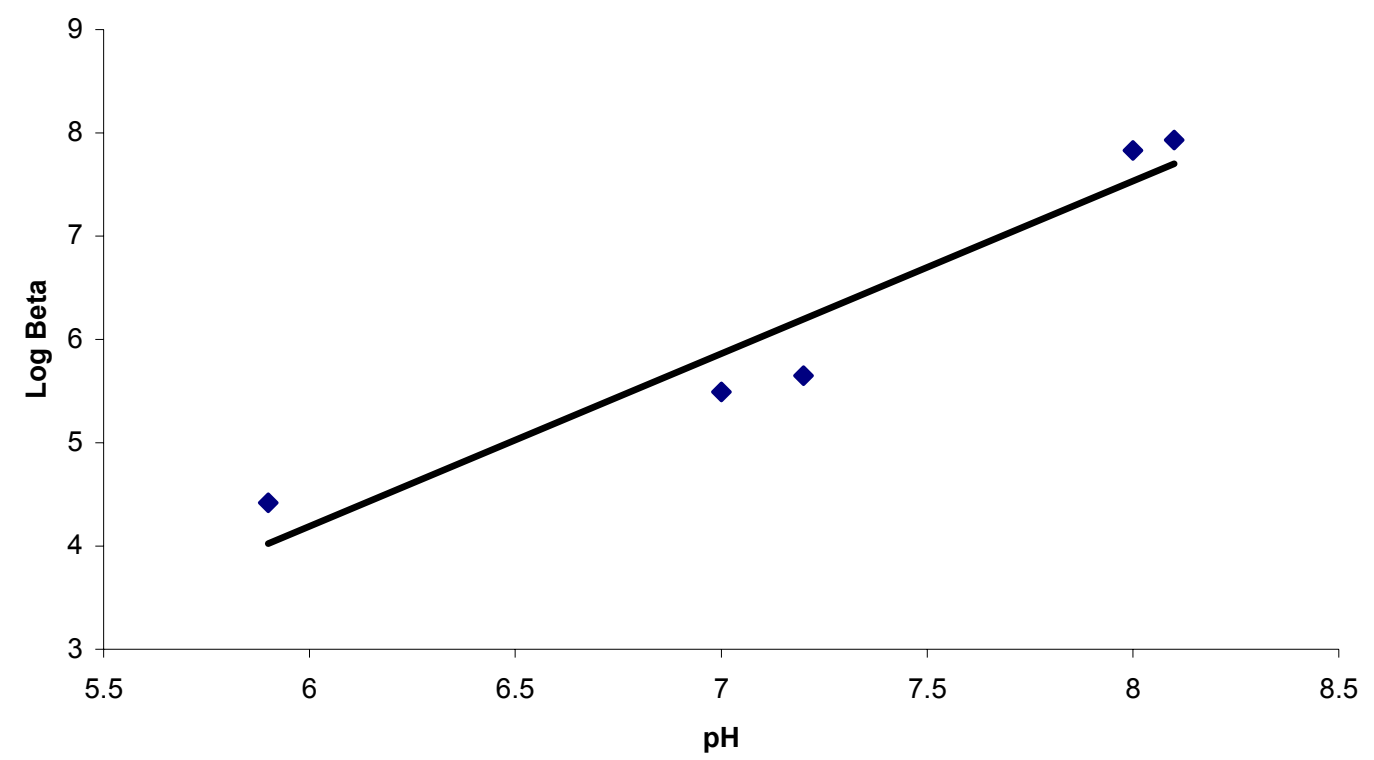


P. Warwick Figure 5. Speciation of $\mathrm{U}(\mathrm{VI})$ from $\mathrm{pH} 5$ to 9.

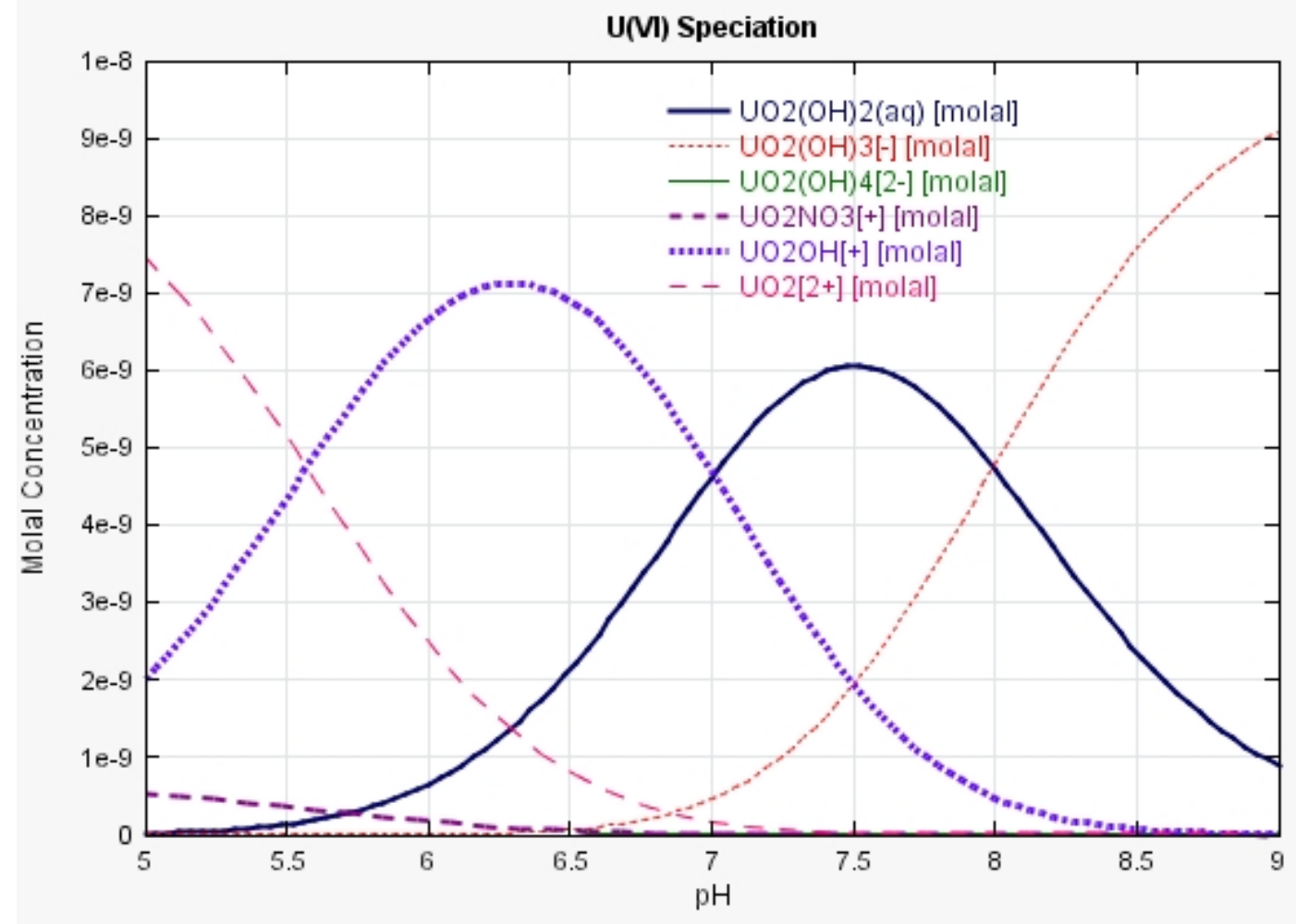


P. Warwick Figure 6. Schubert plots used to investigate the $\mathrm{U}(\mathrm{VI})-\mathrm{BCHA}$ and AHA stoichiometries; near-unit slopes are consistent with $1 \mathrm{U}: 1 \mathrm{HA}$.

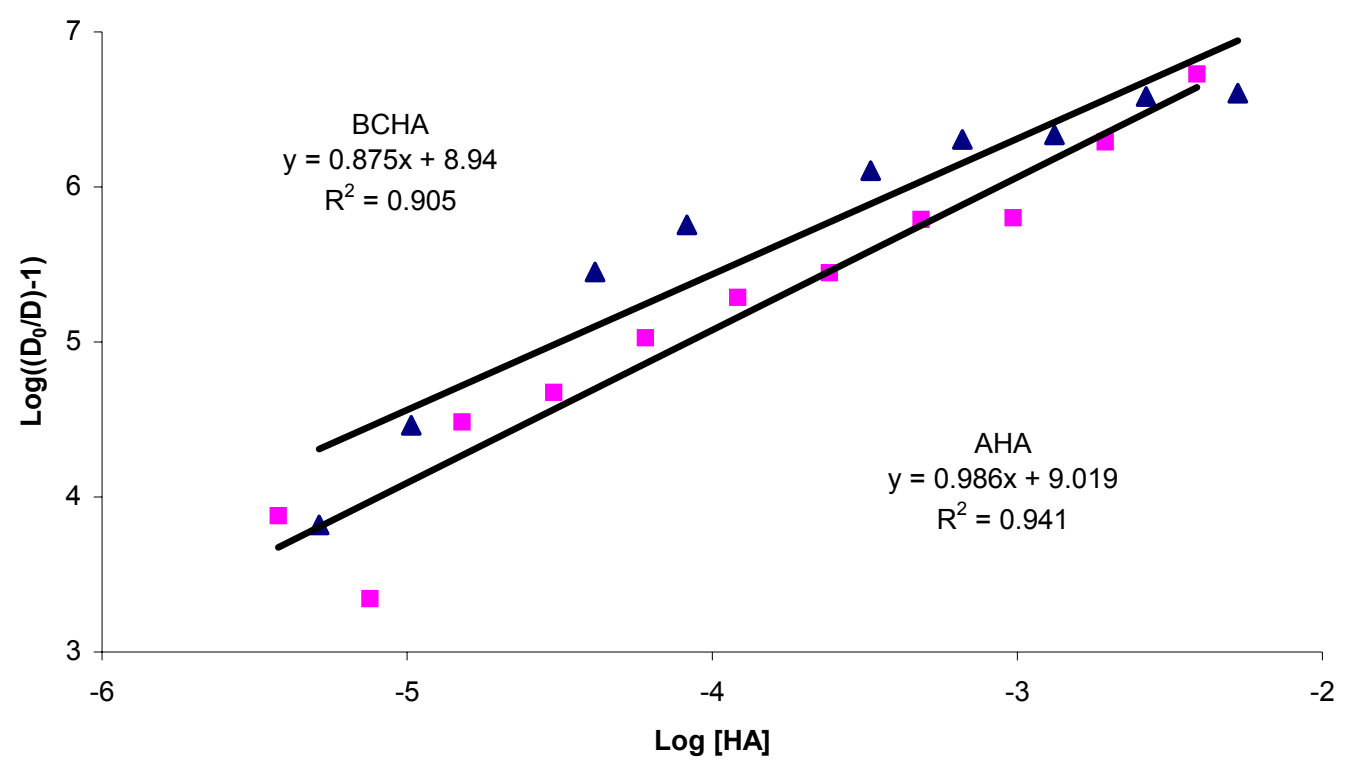




\section{Figures}

Figure 1. Speciation of Uranium(IV) from $\mathrm{pH} 6$ to 9.

Figure 2. Variation of $\mathrm{U}(\mathrm{IV})-\mathrm{BCHA} \log \beta$ values with $\mathrm{pH}$.

Figure 3. Variation of $\mathrm{U}(\mathrm{IV})-\mathrm{AHA} \log \beta$ values with $\mathrm{pH}$.

Figure 4. Variation of $\mathrm{U}(\mathrm{VI})-\mathrm{BCHA} \log \beta$ values with $\mathrm{pH}$.

Figure 5. Speciation of $\mathrm{U}(\mathrm{VI})$ from $\mathrm{pH} 5$ to 9.

Figure 6. Schubert plots used to investigate the $\mathrm{U}(\mathrm{VI})-\mathrm{BCHA}$ and $\mathrm{AHA}$ stoichiometries; near-unit slopes are consistent with $1 \mathrm{U}: 1 \mathrm{HA}$. 